\title{
ASSESSMENT OF EFFICIENCY AND ADEQUACY OF RETENTION TERRACES ${ }^{(1)}$
}

\author{
Antônio Calazans Reis Miranda(2), Danilo Paulúcio da Silva( ${ }^{(3)}$, Eloy \\ Lemos de Mello ${ }^{(4)}$ \& Fernando Falco Pruski ${ }^{(5)}$
}

\begin{abstract}
SUMMARY
Due to losses caused by water erosion, the development of techniques that increase the efficiency of soil conservation practices is fundamental. Terracing of agricultural lands is an important conservation practice. Bearing in mind that improperly built terraces may negatively affect the landscape, the purpose of this work was to evaluate the efficiency as well as the adequacy of retention terraces. Assessments were performed in four terraces implanted in different states, all located in the mideastern region of the state of Minas Gerais. The water storage efficiency of the terraces was determined by comparing the effective with the required storage capacity, as established in the project. Proposals were also made for the adequacy of the assessed terraces, based on the correction of the characteristics that jeopardized storage efficiency. The storage efficiency of three of the four assessed terraces was below the required levels $(0.5-13 \%)$. The main properties influencing storage capacity were: uniformity of ridge crest height, terrace end closure, and the cross section finishing. In two of the three low-efficiency terraces, the correction of these characteristics proved sufficient to raise the storage efficiency to nearly $100 \%$.

Index terms: water erosion, surface runoff, conservation practices, terrace systems.

(1) This research was supported by FAPEMIG (Minas Gerais Research Foundation) and CNPq (The National Council for Scientific and Technological Development, Brazil). Received for publication in June 27, 2011 and approved in November 30, 2011.

(2) Posgraduate student - Doctor in Agricultural Meteorology, Agricultural Engineering Departament, Universidade Federal de Viçosa - UFV (Minas Gerais State, Brazil). E-mail: miranda_acr@yahoo.com.br

(3) Doctor in Agricultural Engineering, Agricultural Engineering Departament - UFV. E-mail: danilopaulucio@gmail.com

(4) Doctor in Agricultural Engineering, Agricultural Engineering Departament - UFV. E-mail: eloymello@gmail.com

(5) Professor in Agricultural Engineering Departament - UFV. E-mail: ffpruski@ufv.br
\end{abstract}




\title{
RESUMO: AVALIAÇÃO DA EFICIÊNCIA E ADEQUAÇÃO DE TERRAÇOS DE RETENÇÃO
}

\begin{abstract}
Em virtude dos prejuizos causados pela erosão hídrica, é fundamental o desenvolvimento de técnicas que permitam o aumento da eficiência de práticas para a conservação do solo. O terraceamento de terras agrícolas consiste em uma importante prática conservacionista. Tendo em vista que terraços construidos de forma inadequada podem levar a consequências negativas para as áreas onde eles foram implantados, o objetivo deste trabalho foi a avaliação da eficiência e da adequação de terraços de retenção. As avaliações foram realizadas em quatro terraços implantados em diferentes propriedades, localizadas na região centro-oeste do Estado de Minas Gerais. A eficiência de armazenamento do terraço foi determinada a partir da comparação entre a capacidade de armazenamento efetiva do terraço e a capacidade de armazenamento necessária, estabelecida no projeto. Foram feitas, ainda, propostas para a adequação dos terraços avaliados, tendo como base a correção das características que comprometeram a eficiência de armazenamento. Três dos quatro terraços apresentaram-se com eficiência de armazenamento abaixo da necessária (entre 0,5 e $13 \%$ ); as principais características que interferiram na capacidade de armazenamento desses terraços foram: a uniformidade da altura da crista, o fechamento das extremidades do terraço e o acabamento da seção transversal. Em dois desses três terraços com baixa eficiência, bastou a adequação das suas características para elevar a eficiência de armazenamento para valores próximos a $100 \%$.
\end{abstract}

Termos de indexação: erosão hídrica, escoamento superficial, práticas conservacionistas, sistemas de terraceamento.

\section{INTRODUCTION}

Water erosion from agricultural land is a critical phenomenon due to the speed at which it happens, as well as the great losses it causes, not only for the agricultural exploration, but also for many other economical activities and for the environment (Nunes \& Cassol, 2008). According to Griebeler et al. (2000), around 600 million tons of agricultural soil are lost in Brazil every year due to the erosion caused by inadequate soil management. Besides, erosion causes problems both for water quality and availability, since it pollutes and silts water streams (Barros et al., 2009), causing floods during the rainy season followed by water shortage in the dry season (Griebeler et al., 2005a).

In view of the losses caused by water erosion, the development of techniques that increase the efficiency of soil conservation is fundamental (Gribeler at al., 2005b). With this purpose, Denardin et al. (2009) suggested the use of conservation practices in agriculture, so as to preserve, improve and optimize natural resources, by means of integrated management of soil, water and biodiversity, adequately adjusted to the agricultural inputs.

Conservation practices can be divided into vegetative, edaphic and mechanical practices. Vegetative practices make use of the vegetation as soil protection against the direct action of rain, minimizing the erosion process, while edaphic practices are those that aim at cultivation systems that maintain or improve soil fertility (Miranda et al., 2004). The approach to these practices is widely described in the context of the no-tillage system conservation practice (Denardin et al., 2009).

Although the soil cover, maintained in no-tillage systems, plays an important role in dissipating the eroding power of rain (Cogo et al., 2003), there are critical limits for slope length where this dissipation capacity is exceeded and, consequently, the water erosion process is initiated (Denardin et al., 2009; Leite et al., 2009). For these cases, Miranda et al. (2004) proposed the use of complementary procedures to reduce the speed of surface runoff, which would decrease the ability of soil detachment and silt transportation associated to runoff; this is possible by the implantation of mechanical barriers, e.g., terraces, end drains, rain water infiltration basins, and dams.

Terracing of agricultural land represents one of the most known and used practices by farmers to control water erosion, representing the most important mechanical practice for erosion control (Griebeler et al., 2000; Miranda et al., 2004). It consists in building terraces (structures consisting of channels and a dam, also known as ridge), transversally to the terrain slope, creating physical obstacles that reduce the runoff speed and mitigate the water movement on the soil surface (Mafra, 2003; NRCS, 2010).

Terraces can be classified in a number of ways (FAO, 2000). One of the most important criteria is the terrace function (destination of intercepted 
water). By this criterion, they can be classified as: retention, infiltration or level terraces - consisting of a channel built along the contour lines with blocked ends such that the surface runoff can be retained and eventually infiltrated into the channel; and graded or diversion terraces - built with a non-erosive slope, leading the excess water to a safe outlet. Therefore, a level terrace is not necessarily a retention terrace, since if its ends are not blocked, it functions as a drainage terrace.

A terracing system can be beneficial in a number of ways for the area where it is constructed, such as: splitting the slope in several segments, resulting in the reduction of the amount and rate of surface runoff and a consequent reduction of erosion activity causing nutrient losses; the increase of water availability for crops; a notable decrease in the peak flow of water courses (Huang \& Zhang, 2004; Posthumus \& De Graaf, 2006; Zhang et al., 2008; Liu et al., 2011).

The construction costs of a terracing system are relatively high (Griebeler et al., 2000). In addition to the financial aspect, it is important to remember that the breaking of one terrace can lead to the destruction of others downstream, not only accelerating the erosion process, but also causing great losses to the cultivated area (Pruski, 2009). Therefore, extreme care must be taken during the stages of planning and implementing these systems.

Terraces are built in locations with distinct weather characteristics, soil types, land topography, cultivation systems, and using different types of equipment. Therefore, the use of models, which are simplified mathematical representations of natural processes, and which make it possible to simulate the numerous conditions involved in the represented processes (Hoogenboom, 2000; Tedeschi, 2006), help to carry out the project with a greater degree of efficiency and reliability of these structures. On this issue, Griebeler at al. (2005a,b) developed a model for the design and location of terraces using as input parameters, among other local data, the digital terrain models generated by the Geographical Information Systems (GIS).

Despite the advantages and availability of models for the terracing system project, another essential aspect is the system implementation stage in the field. Even in cases of a satisfactory project development, serious problems can occur in the terraced area if the project is not properly performed. In addition, the terrace efficiency also depends on whether the characteristics of finishing of the ridge structure, of the terrace cross section and, as in the case of retention terraces, of end closure are in compliance with the project requirements (Bertoni \& Lombardi Netto, 1990; Huydson, 1995; Pruski, 2009).
Studies indicate that a number of retention terraces are being constructed that do not meet the project standards (Griebeler et al., 1998). This way, checking the relationship between the effective retention capacity of the volume of surface runoff and the required storage capacity, according to the local conditions, is of major importance for the adequacy of this kind of terrace. Thus, the purpose of this study was to evaluate the storage efficiency of retention terraces and propose alternatives for the adequacy of their characteristics to optimize their storage efficiency.

\section{MATERIALS AND METHODS}

Four retention terraces, constructed on different rural properties in the mid-eastern region of the state of Minas Gerais were evaluated.

Of the four terraces evaluated, two were Nichols terraces, one with a medium base (Terrace 1 ), and the other a wide base (Terrace 2). The other two were medium-base Manghum terraces (Terraces 3 and 4), according to a FAO (2000) classification of terrace construction patterns.

The soil at the locations of the terraces was an Oxisol, according to Embrapa (2006).

Taking into consideration that a retention terrace is considered adequate when its effective storage capacity is equal or superior to the required, a methodology of Pruski (2009) was used to assess the storage capacity of the retention terraces. Below, the evaluation parameters and methodology are described in more detail.

\section{Required storage capacity}

The required storage capacity $(\mathrm{Vr})$ indicates the characteristics a terrace must have for total operation efficiency in retaining the surface runoff from the surrounding contributing area. Thus, to obtain the $\mathrm{Vr}$, a survey of the terrace contributing area is required as well as the definition of the surface runoff depth.

The contributing area (CA) of each terrace was calculated as the product of the average distance between the evaluated terrace and the terrace upstream by its length.

The maximum surface runoff depth (SR) was estimated according to the methodology developed by Pruski et al. (1997a). The SR value was determined using ${ }^{\circledR} T E R R A C E ~ 4.1$ (www.ufv.br/dea/gprh), based on the soil-climate patterns of each location of the terraces, such as: basic infiltration rate and return period for the expected rainfall. 
Value corresponding to the expected rainfall was estimated based on equations of intensity, duration and frequency (Mello et al., 2001; Bazzano et al., 2007). The parameters of Intensity, Duration and Frequency (I-D-F) were estimated for each terrace location, according to the methodology of Pruski et al. (1997b), using Plúvio 2.1 software (www.ufv.br/ dea/gprh).

For the return period of the expected rainfall, a 10-year value was adopted, following practical recommendations for this kind of work (Carvalho 1988, cited by Mello et al., 2001). For the basic infiltration rate, a value of $30 \mathrm{~mm} \mathrm{~h}^{-1}$ was adopted, taking into consideration that the soil of the terraces was an Oxisol (Barcelos et al., 1999; Panachuki et al., 2006).

The required volume $\left(\mathrm{Vr} / \mathrm{m}^{3}\right)$ was calculated for each evaluated terrace, according to the equation:

$$
\mathrm{Vr}=\mathrm{SR} \mathrm{CA}
$$

where SR = maximum depth of surface runoff, $\mathrm{m}$; and $\mathrm{CA}=$ contributing area, $\mathrm{m}^{2}$.

\section{Effective storage capacity}

The effective storage capacity of a retention terrace depends on the ridge uniformity, the proper finishing of the channel cross section, and the closure of its ends. Thus, a planialtimetric survey was performed in the four evaluated terraces to detect possible irregularities for these characteristics, using an optical level, a leveling rod, and a measuring tape.

To detect the lowest ridge height of the terrace, at least 20 measurements were performed along the ridge, mainly at the points that were visibly lower than the others. At this stage, the height of the closures of the terrace end were also measured.

For the calculation of the cross section, 3-5 sections were randomly chosen. Figure 1 represents an illustrative diagram of the profile survey of the terrace cross section, showing the measured data: ridge crest height $(\mathrm{RH})$; height of the terrace bottom $\left(\mathrm{CB}_{1}\right)$; height of terrace bottom $2\left(\mathrm{CB}_{2}\right)$ of trapezoidal-shaped sections; height of upstream slope channel (UC); horizontal distance between ridge crest and terrace bottom $\left(\mathrm{RH}-\mathrm{CB}_{1}\right)$; horizontal distance between ridge and terrace bottom $2(\mathrm{RH}$ $\mathrm{CB}_{2}$ ) in the cases of trapezoidal sections; distance between ridge and upstream slope channel $(\mathrm{RH}$ UC). The point corresponding to the upstream slope channel (UC) is a point in the upstream terrain with the same height of the ridge crest of the measured cross section.

The effective storage areas of the terraces ( $\overline{\mathrm{Ar}}$ ) were calculated taking into consideration the average value of the areas in all measured cross sections, either in triangular or trapezoidal shapes, and the lowest points detected either on the ridge crest or at the end closures (Figure 2).

The estimates of effective water storage capacity of the terrace were then calculated according to the equation:

$$
\begin{aligned}
& \mathrm{Ve}=\overline{\mathrm{A}} \mathrm{r} \mathrm{Lt} \\
& A r=\left\{\begin{array}{lll}
A_{1}+A_{3} & \ldots \ldots \ldots \ldots . . . & \text { triangular base } \\
A_{1}+A_{2}+A_{3} \ldots \ldots \ldots . . . & \text { trapezoidal base }
\end{array}\right.
\end{aligned}
$$

where $\mathrm{Ar}=$ actual average area of cross sections measured at the terrace channel, in $\mathrm{m}^{2}$; and Lt $=$ terrace length, in $\mathrm{m}$.

\section{Storage efficiency}

After calculating the values $\mathrm{Ve}$ and $\mathrm{Vr}$, the storage efficiency was estimated (E, \%) for each terrace by the equation:

$$
\mathrm{E}=\mathrm{Ve} / \mathrm{Vr} 100
$$

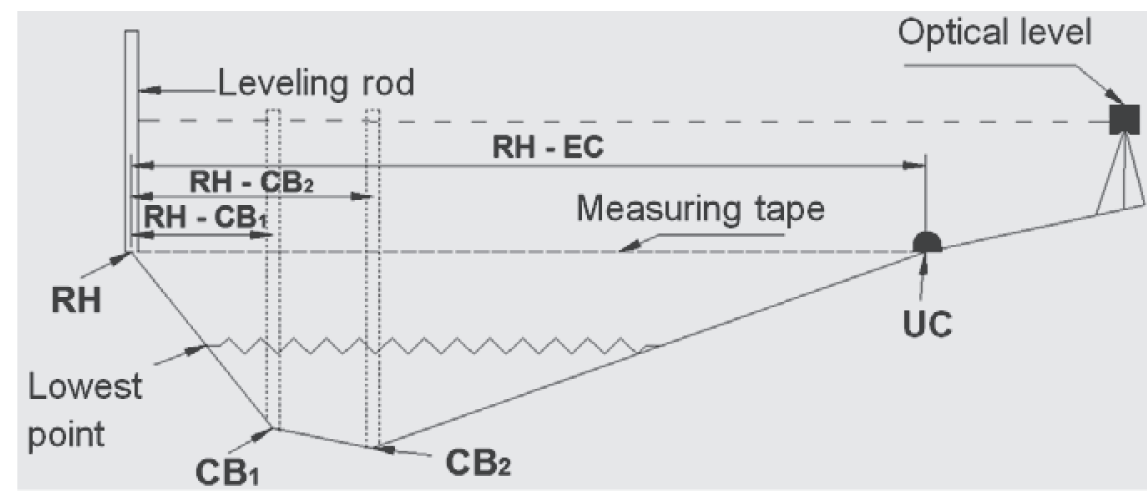

Figure 1. Survey of profiles of terrace cross sections. Modified from PRUSKI (2009). 
(a)

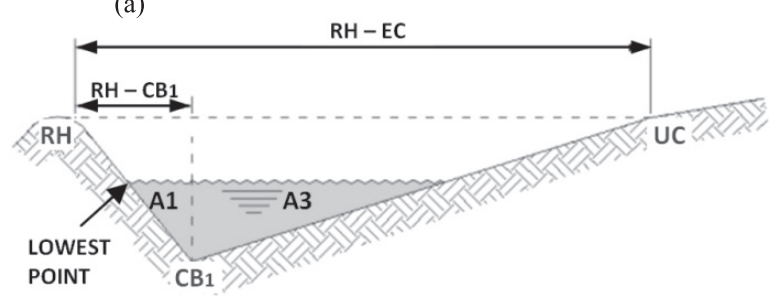

(b)

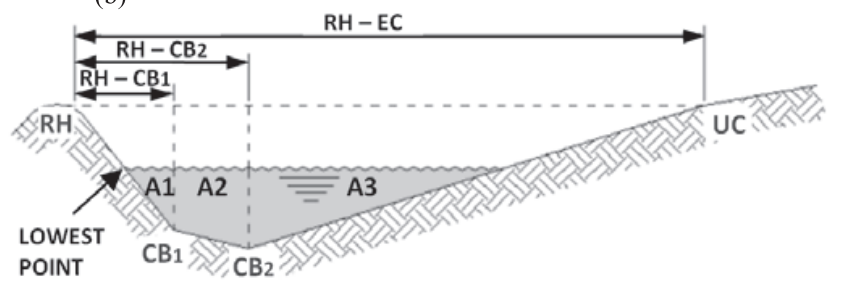

Figure 2. Cross section areas of triangular-shaped terrace channels (a) and trapezoidal-shaped terrace channels (b). Source: Pruski (2009).

A storage efficiency analysis was made individually for each terrace, simultaneously with the analysis of the determinant characteristics of effective storage capacity of terraces.

In the terraces with an $\mathrm{E}$ value below $100 \%$, modifications of the characteristics that affected the effective storage capacity were simulated, aiming at improving the efficiency of these terraces.

\section{RESULTS AND DISCUSSION}

The results of the assessment of the four retention terraces are presented separately, as well as the alternatives for their adaptation.

\section{Assessment of Terrace 1}

The estimated SR from the contributing area of Terrace 1 was $50.1 \mathrm{~mm}$. The average distance between Terrace 1 and the upstream terrace was $26.71 \mathrm{~m}$, and the terrace length $197.36 \mathrm{~m}$, resulting in a $\mathrm{Vr}$ value of $264.13 \mathrm{~m}^{3}$.

Figure 3 presents results of the survey for the four cross section profiles, the height of the lowest point in the ridge, and the height corresponding to the closure of the ridge, at the end of Terrace 1.
Evidence was found that the terrace has a storage capacity of surface runoff of only $34.27 \mathrm{~m}^{3}$ (Ve), when, actually, it should be able to retain $264.13 \mathrm{~m}^{3}$ (Vr), when taking both the contributing area and surface runoff depth into consideration.

The terrace therefore have a ridge height of up to $0.7 \mathrm{~m}$, although the presence of a low point in the ridge (lowest height of the crest) of $0.30 \mathrm{~m}$, limited the effective storage capacity of the terrace to only $13 \%$ of its requirement. Therefore, the storage efficiency (E) is below the percentage observed in the study by Griebeler et al. (1998), which varied between 16.2 and $79.6 \%$. In that work, however, the authors used the theoretical or potential volume as a comparative base for the real storage volume, based on the greatest cross section of the terrace, rather than on the storage capacity defined in the project, as considered in the evaluation methodology used in this paper. This was due to the fact that the purpose of the study of Griebeler et al. (1998) was to analyze, mainly, the spatial variability of the cross section of the assessed terraces.

The low point on the ridge that reduced the terrace storage capacity was represented in a diagram of the ridge profile (Figure 4).

More than one low point reducing the storage capacity of the terrace was observed (Figure 4). The ridge height data indicate problems with
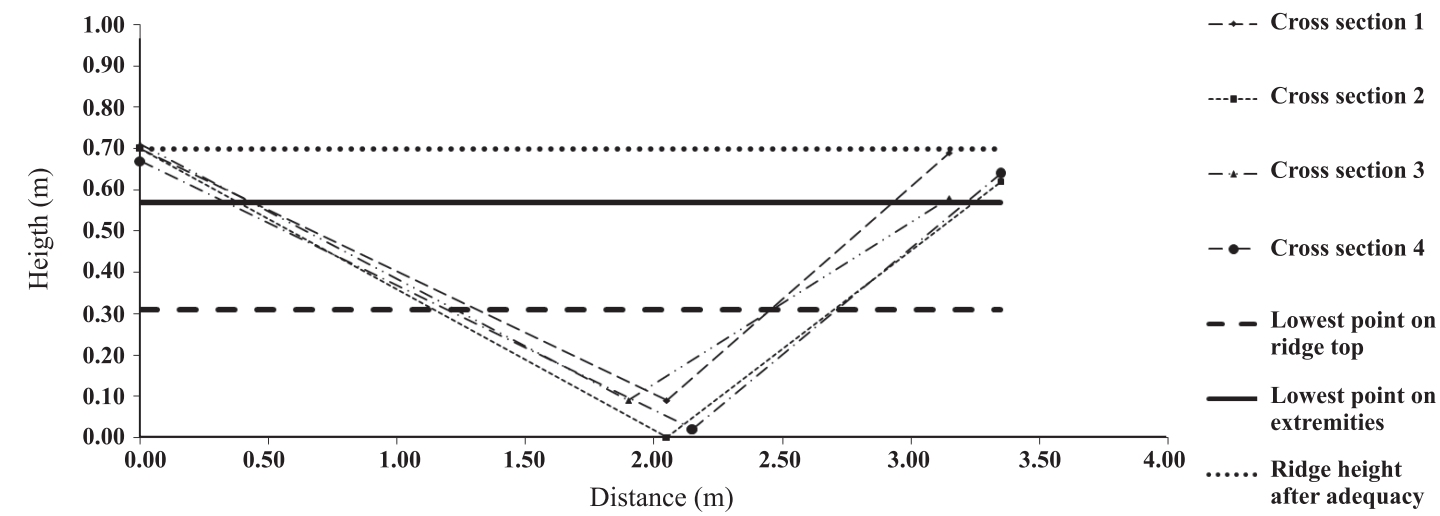

Figure 3. Cross section profile of the channel of Terrace 1. 


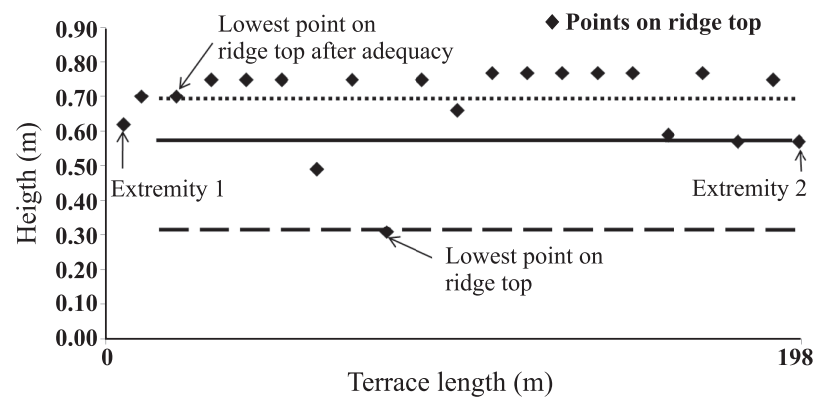

Figure 4. Profile of the ridge height of Terrace 1.

the building pattern of the terrace with a lack of uniformity of the ridge height, that is, elevating the lowest identified point would not be enough, however, the correction of the whole ridge would give the ridge the minimum height according to the conditions established in the project.

Lower points on the ridge, aside from compromising the storage capacity, represent a risk factor for the terrace. The ridge is the most fragile part of the terrace, since it was constructed by piling the soil, leading to a reduced resistance to rupture. Consequently, if a terrace should overflow over this less stable ridge, the erosion at the overflowing point tends to increase. In addition, as the overflow point tends to be lowered due to erosion, the runoff volume in this section will increase.

The overflowing of a terrace also tends to cause additional consequences, which is the probable overflowing of the downstream terraces, i.e., the effective storage capacity of downstream terraces would not be able to retain the additional volume that was then supposed to be stored in the upstream terrace. Therefore, the rupture of one terrace could eventually result in a knock-on effect of destruction of all downstream terraces.

The first step to adjust the effective storage capacity to the required storage capacity consists in ensuring the uniformity of the ridge height of
Terrace 1 (Figures 2 and 3). It was found that, when the ridge was lifted to a minimum height of $79 \mathrm{~cm}$, the storage capacity of the terrace increased from 34.27 to $135.05 \mathrm{~m}^{3}$.

However, although the standardization of the ridge could provide an increase of about four times the volume of the terrace storage capacity, this procedure would still not be enough to ensure the storage of the expected overflow volume from the contributing area, of $264.13 \mathrm{~m}^{3}$. One of the possible alternatives of optimizing the effective terrace storage capacity would be to lift the ridge height and expand the terrace cross section.

By elevating the terrace height by $20 \mathrm{~cm}$, including a safety margin of $10 \mathrm{~cm}$ in relation to the corresponding height of the extremity closure (Figure 5), the effective storage capacity of Terrace 1 would rise from 135.05 to $265.2 \mathrm{~m}^{3}$, which would correspond to a storage efficiency of $100.4 \%$. In this case, the need of increasing the terrace cross section is eliminated.

A third alternative of adjusting the terrace storage capacity would be by reducing the required storage capacity, by building of an upstream terrace. This would split the terrace contributing area, and, consequently, could reduce the required storage capacity from $264.13 \mathrm{~m}^{3}$ to $128.54 \mathrm{~m}^{3}$. This procedure would also be sufficient to raise the terrace storage efficiency (E) to $105.1 \%$. On the other hand, the alternative of building an upstream terrace would decrease the average distance among terraces in that area from 26.71 to $13.4 \mathrm{~m}$, which could, for instance, hamper the use of certain agricultural equipment in the area. Thus, this measure is only indicated in specific situations where the spacing of terraces is greater.

It is further worth mentioning that, after completing the adjustments of the terrace, it is highly important to check the end point closures, also taking the extra ridge height of at least $10 \mathrm{~cm}$ into consideration, as a safety margin.

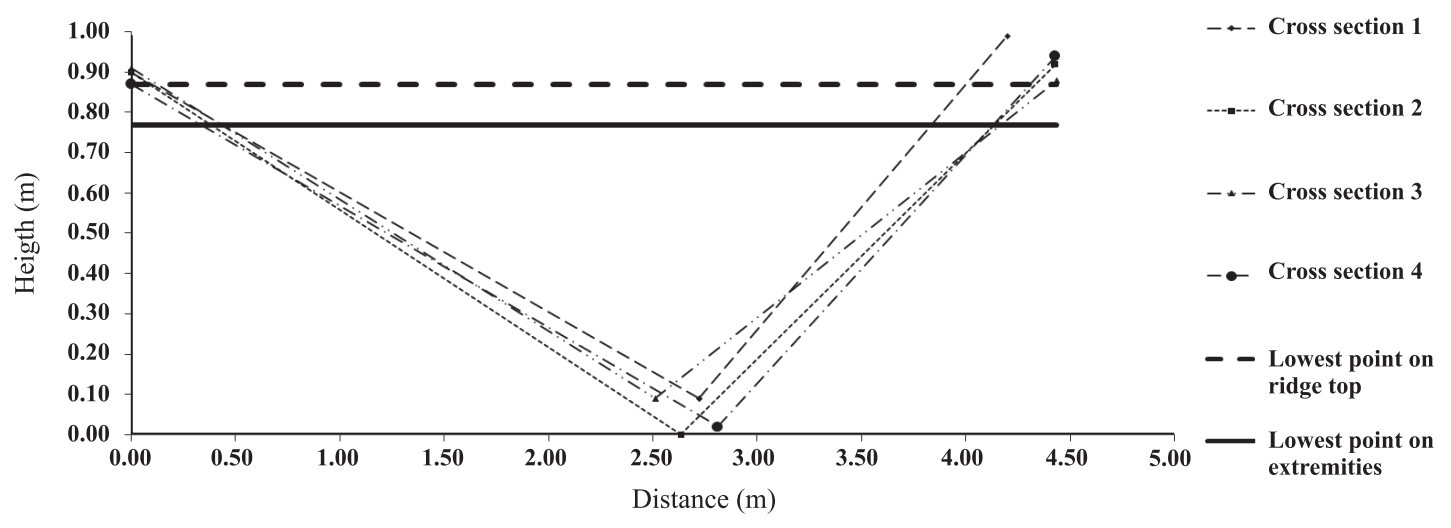

Figure 5. Cross section profile of the channel of Terrace 1 after simulation of ridge height elevation. 


\section{Evaluation of Terrace 2}

The estimated SR value from the contributing area of Terrace 2 was $43.9 \mathrm{~mm}$. The average distance between Terrace 2 and the corresponding upstream terrace was $59 \mathrm{~m}$, with a length of $145 \mathrm{~m}$, resulting in a Vr value of $375.5 \mathrm{~m}^{3}$.

The results of the survey of three sections of Terrace 2 are shown in figure 6 , where the lowest ridge heights are indicated, as well as the lowest height at the end points.

The effective storage capacity of Terrace 2 was estimated at $426.92 \mathrm{~m}^{3}$, resulting in a storage efficiency of $113.7 \%$. Therefore, the storage efficiency of this terrace was consistent with the requirement of the catchment area, according to the evaluation method used. The efficiency of the storage capacity was given by the adequacy of the characteristics of the terrace, i.e., the ridge construction was uniform, the finishing of the section good and its end points duly blocked.

This terrace even had an extra ridge height, of around $10 \mathrm{~cm}$ above the height for end point closure. Therefore, it even matches the safety criterion as recommended for minimizing the likelihood of overflow over the ridge at a possible lowered point of the crest.

\section{Evaluation of Terrace 3}

The estimated SR value corresponding to the contributing area of Terrace 3 was $25.4 \mathrm{~mm}$. The average distance between Terrace 3 and the upstream terrace was $98.25 \mathrm{~m}$, and the length $409 \mathrm{~m}$, corresponding to a $\mathrm{Vr}$ value of $1,020.65 \mathrm{~m}^{3}$.

The line representing the height of Terrace 3 end points was near zero (Figure 7), therefore indicating that the ends (or, at least, one of its ends) was not blocked, limiting the effective storage capacity to only $5.36 \mathrm{~m}^{3}$. Taking into consideration that the required storage capacity was $1,020.65 \mathrm{~m}^{3}$, the actual storage efficiency of Terrace 3 corresponded to a value of only $0.5 \%$.

For Terrace 3, problems related to points of lower ridge height were also observed (Figure 7). Similarly to Terrace 1 , the uniformity pattern of ridge height of Terrace 3 was inadequate. This way, aside from closing the terrace ends, it was also necessary to standardize the ridge height (Figure 8) to increase the effective storage efficiency to a satisfactory level.

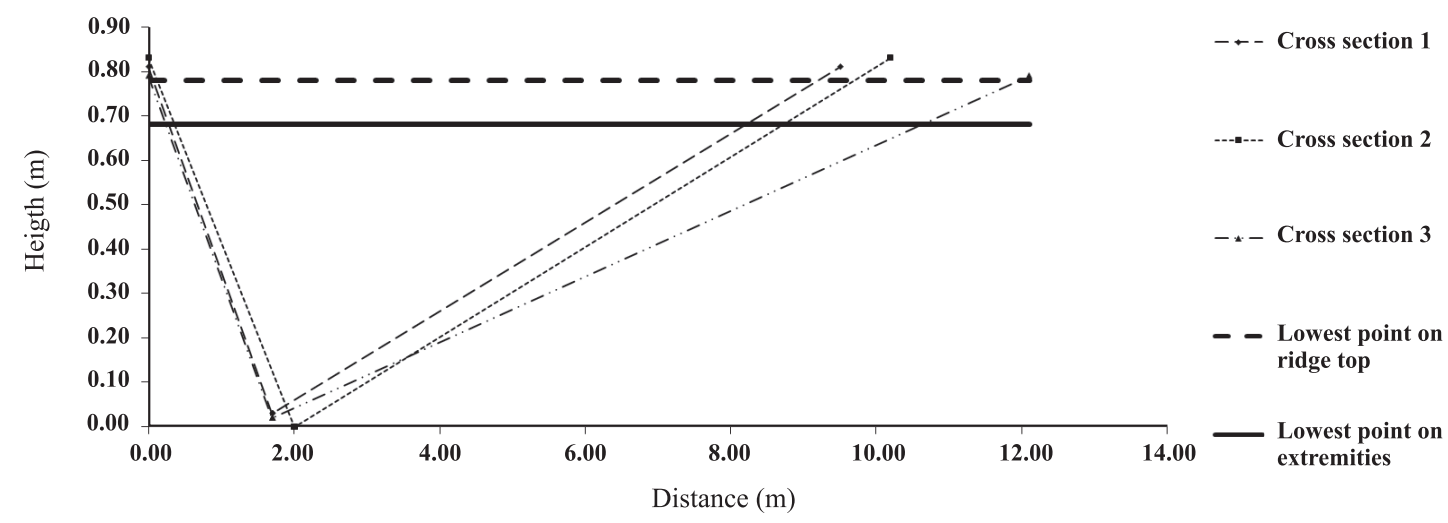

Figure 6. Cross section profile of the channel of Terrace 2.

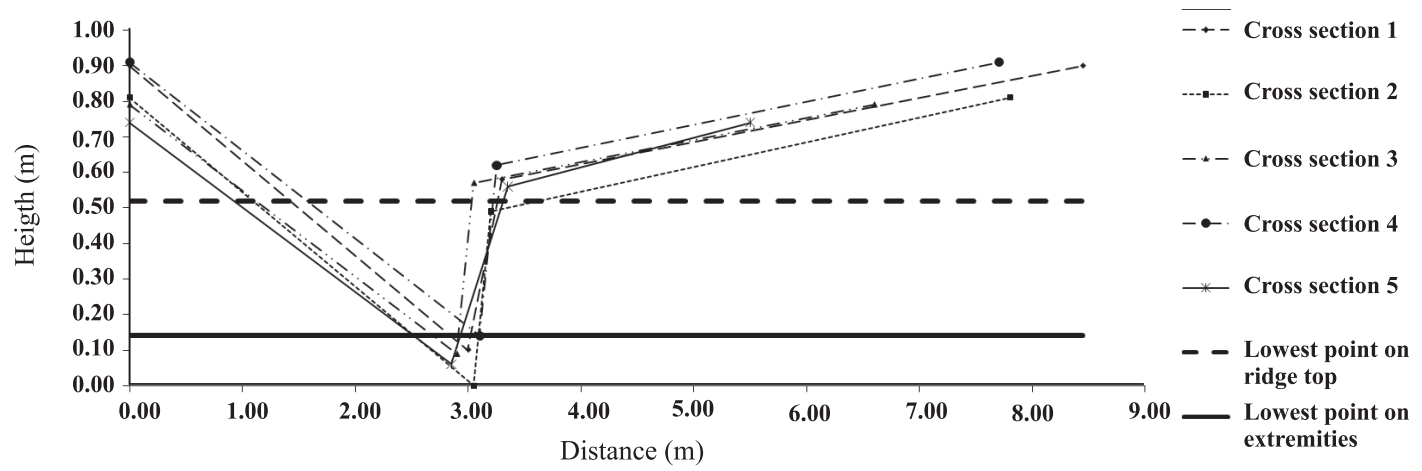

Figure 7. Original cross section profile of the channel of Terrace 1. 
When considering the closing of the ends and standardization of the ridge height (Figure 8), it was observed that the storage capacity of Terrace 3 , with previously only $5.36 \mathrm{~m}^{3}$, had increased to $601.49 \mathrm{~m}^{3}$. But, even after raising the ridge and blocking the ends, the effective storage capacity of the terrace still corresponded to only $58.9 \%$ of the required volume.

The adjustment suggested for Terrace 1 (raising of the ridge height and building of an intermediate upstream terrace) could possibly be applied to Terrace 3. However, this terrace has a characteristic not found in Terrace 1, which is the inadequate finishing of the cross section. According to Pruski (2009), the most common feature of terraces with finishing problems at the channel cross section is the presence of a step at the interface of the channel and the terrain upstream the terrace (Figures 6 and 7). Such irregularities of the terrace cross section were also reported by Griebeler et al. (1998). These authors reiterate that irregularities can expressively hamper the terrace efficiency. To solve this situation, the most adequate solution would be modifications aiming at a better finishing of the cross section so as to increase the useful storage area and, consequently, increase the effective storage capacity.
A modification of the finishing of the cross section by breaking the step at the channel entrance of Terrace 3 was simulated (Figure 9).

When comparing Figures 8 and 9, an increase in the average effective area ( $\overline{\mathrm{A}} \mathrm{r}$ ) of the cross section of $1.47 \mathrm{~m}^{2}$ of the terrace without the cross section finishing was observed, and of $2.69 \mathrm{~m}^{2}$, for the terrace with the cross section finishing. The increase of about $83 \%$ in the effective terrace area due to the finishing operations at the section induced a rise in Ve to $1102.01 \mathrm{~m}^{3}$, making the terrace adequate to receive a volume corresponding to $\operatorname{Vr}(\mathrm{E}=108 \%)$.

\section{Evaluation of Terrace 4}

Terrace 4 is in the same region and has the same kind of soil as Terrace 3, therefore, the estimated SR value from its contributing area was also $25.4 \mathrm{~mm}$. The average distance between Terrace 4 and its upstream terrace was $66.61 \mathrm{~m}$, and the length $556.9 \mathrm{~m}$, resulting in a $\mathrm{Vr}$ value of $942.22 \mathrm{~m}^{3}$.

The profile survey of the Terrace 4 cross sections (Figure 10), shows the lowest ridge height and lowest end height.

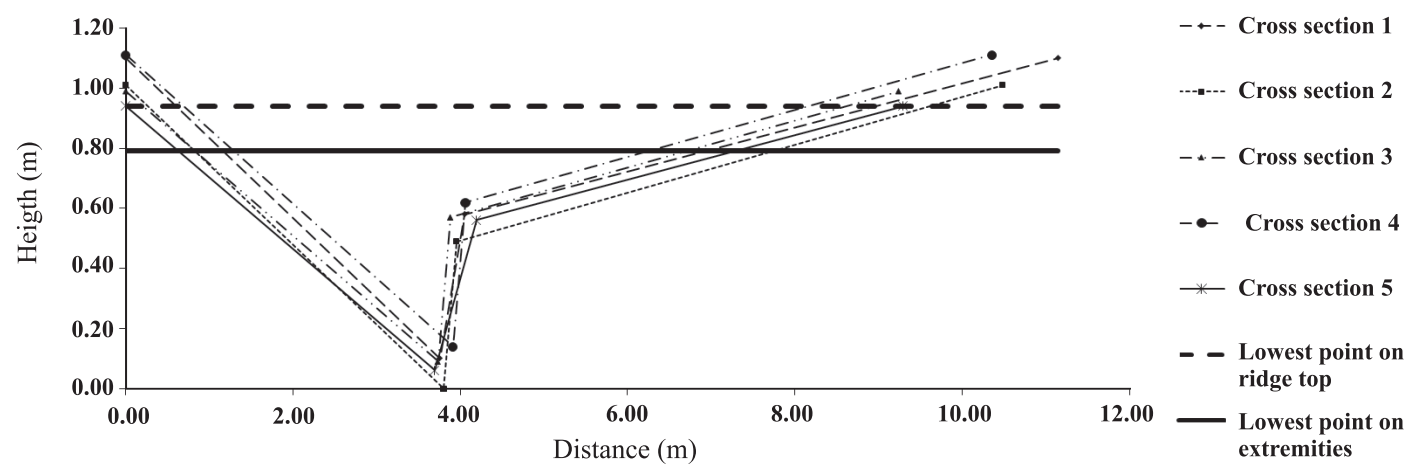

Figure 8. Profile of Terrace 3 cross section after simulation of raising the ridge height and closing the terrace ends.

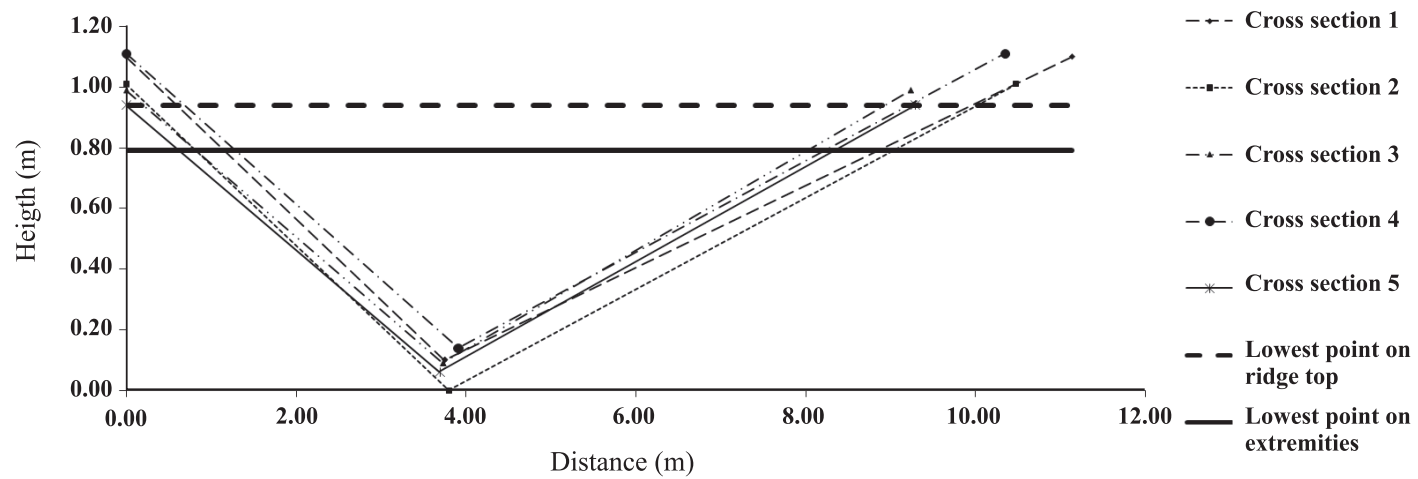

Figure 9. Profile of Terrace 3 cross section after adaptation. 


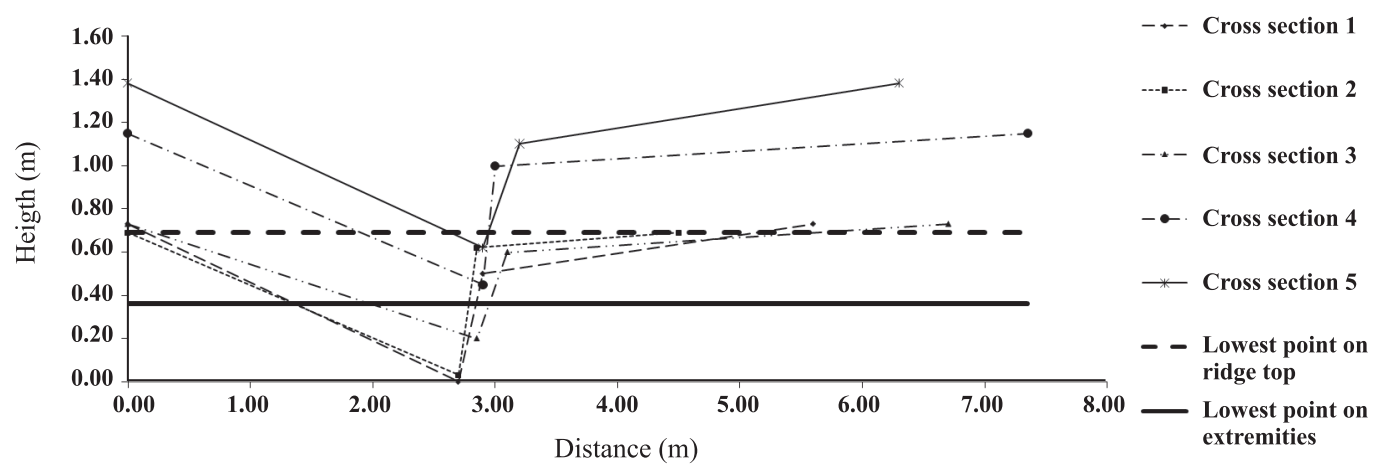

Figure 10. Profile and results of Terrace 4 evaluation.

Terrace 4 , similarly to Terrace 3 , has problems related to the ridge height uniformity, and to the closure point height of the terrace and cross section. However, an aggravating factor in the characteristics of this terrace is that it was built erroneously on a slope. The grade of the terrace can be observed by the gradual increase of levels of the cross section profiles 1 through 5 .

A terrace can be designed to operate in gradient (graded terrace or diversion terrace) provided that the technical characteristics for this kind of usage are taken into consideration. However, Terrace 4 had been designed as a retention, but was built as a graded terrace. Terrace 3, although levelled, could also be considered a graded terrace since its ends had not been closed.

Problems related to the construction of Terrace 4 resulted in an effective storage capacity of $64.5 \mathrm{~m}^{3}$, which corresponds to a storage efficiency of only $6.8 \%$. Considering the correction of the elevation of $23 \mathrm{~cm}$ at the closing point at the extremity with the lowest terrace height and, also, adjustment of the cross section, the effective storage capacity would increase to $386.33 \mathrm{~m}^{3}$, corresponding to $41 \%$ of the required storage capacity. This shows that these measures were insufficient to ensure an adequate storage efficiency of this terrace.

Therefore, the correction of the problems related to terraces built erroneously with a slope is complicated and involves additional costs, since a new topographical survey would be necessary for contour demarcation and terrace re-construction.

\section{CONCLUSIONS}

1. For Terrace 1, problems were detected related to the ridge height uniformity, leading to a storage efficiency of only $13 \%$.

2 . Terrace 2 was the only one with no problems in relation to its characteristics, with a storage efficiency of $113.7 \%$, i.e., adequate for the area where it had been built.

3. For Terrace 3 , problems were observed in terms of the ridge height uniformity, end closure, as well as finishing of the cross section. These problems reduced the storage efficiency to only $0.5 \%$.

4. The greatest problem of Terrace 4, aside from the issues related to ridge height uniformity and finishing of cross section, was that it had been mistakenly constructed on a slope, reducing the storage efficiency to only $6.8 \%$.

5. Simulations for the correction of the characteristics considered inadequate of each terrace were important for observations on the magnitude with which each one reduced efficiency. Furthermore, these simulations were important to determine the most feasible alternatives to adjust the terrace retention capacity.

\section{LITERATURE CITED}

BARROS, L.S.; VALE JR., J.F.; SCHAEFER, C.E.G.R. \& MOURAO JUNIOR, M. Perdas de solo e água em plantio de Acacia mangium wild e savana em Roraima, norte da Amazônia. R. Bras. Ci. Solo, 33:447-454, 2009.

BARCELOS, A.A.; CASSOL, E.A. \& DENARDIN, J.E. Infiltração de água em um Latossolo vermelho-escuro sob condições de chuva intensa em diferentes sistemas de manejo. R. Bras. Ci. Solo, 23:35-43, 1999.

BAZZANO, M.G.P.; ELTZ, F.L.F. \& CASSOL, E.A. Erosividade, coeficiente de chuva, padrões e período de retorno das chuvas de Quaraí, RS. R. Bras. Ci. Solo, 31:1205-1217, 2007.

BERTONI, J. \& LOMBARDI NETO, F. Conservação do solo. 4.ed. São Paulo, Ícone, 1990. 355p.

COGO, N.P.; LEVIEN, R. \& SCHWARZ, R.A. Perdas de solo e água por erosão hídrica influenciadas por métodos de preparo, classes de declive e níveis de fertilidade do solo. R. Bras. Ci. Solo, 27:743-753, 2003. 
DENARDIN, J.E.; SANTI, A.; WIETHOLTER, S.; SILVA JUNIOR, J.P. \& FAGANELLO, A. Cultivo de trigo - Manejo e conservação de solo. Sistemas de produção. EMBRAPA Trigo, 2009. (Sistemas de produção, 4) Available at: <http:// sistemasdeproducao.cnptia.embrapa.br/ FontesHTML/ Trigo/CultivodeTrigo/solo.htm>. Accessed: 01 Jun. 2011.

EMPRESA BRASILEIRA DE PESQUISA AGROPECUÁRIA EMBRAPA. Sistema brasileiro de classificação de solos. 2.ed. Rio de Janeiro, Embrapa Solos, 2006. 306p.

FAO. Manual on integrated soil management and conservation practices. Rome, 2000. 230p. (FAO Land and Water Bulletin 8) Available at: <ftp://ftp.fao.org/agl/agll/docs/lw8e.pdf>. Accessed: 02 Jun. 2011.

GRIEBELER, N.P.; PRUSKI, F.F.; BRAGA, A.P. \& ABRAHÃO, W.A.P. Variabilidade espacial da seção transversal de terraços posicionados em nível. R. Bras. Eng. Agric., 6:111, 1998.

GRIEBEler, N.P.; CARVAlho, D.F. \& MATOS, A.T. Estimativa do custo de implantação de sistema de terraceamento, utilizando-se SIG. Estudo de caso: Bacia do Rio Caxangá, PR. R. Bras. Eng. Agríc. Amb., 4:299-303, 2000 .

GRIEBELER, N.P.; PRUSKI, F.F.; TEIXEIRA, A F. \& OLIVEIRA, L.F.C. Software para o planejamento e a racionalização de sistemas de terraceamento em nível. Eng. Agríc, 25:841851, 2005a.

GRIEBELER, N.P.; PRUSKI, F.F.; TEIXEIRA, A.F. \& SILVA, D.D. Modelo para o dimensionamento e a locação de sistemas de terraceamento em nível. Eng. Agríc, 25:696704, 2005b.

HOOGENBOOM, G. Contribution of agrometeorology to the simulation of crop production and its applications. Agric. For. Meteorol., 103:137-157, 2000.

HUDSON, N. Soil conservation. Ames, Iowa State University Press, 1995. 391p.

HUANG, M. \& ZHANG, L. Hydrological responses to conservation practices in a catchment of the Loess Plateau, China. Hydrol. Process., 18:1885-1898, 2004. DOI: 10.1002/ hyp. 1454 .

LEITE, M.H.S.; COUTO, E.G.; AMORIM, R.S.S.; COSTA, E.L. \& MARASCHIN, L. Perdas de solo e nutrientes num Latossolo Vermelho-Amarelo ácrico típico, com diferentes sistemas de preparo e sob chuva natural. R. Bras. Ci. Solo, 33:689-699, 2009.

LIU, X.; HE, B.; LI, Z.; ZHANG, J.; WANG, L. \& WANG, Z. Infuence of land terracing on agricultural and ecological environment in the loess plateau regions of China. Environ. Earth Sci., 62:797-807, 2011.
MAFRA-Ministry of Agriculture, Food and Rural Affairs. Soil Erosion - Causes and Effects. FactSheet. Ontário, Canadá. 2003. ISSN: 1198-712X. Available at: <www.omafra.gov. on.ca/ english/engineer/facts/87-040.htm\#>. Accessed: 25 Nov. 2010.

MELLO, C.R.; FERREIRA, D.F.; SILVA, A.M. \& LIMA, J.M. Análise de modelos matemáticos aplicados ao estudo de chuvas intensas. R. Bras. Ci. Solo, 25:693-698, 2001.

MIRANDA, J.H. Infiltration terrace design by volumetric balance method. R. Bras. Eng. Agríc. Amb., 8:2-3, 2004.

NRCS - Natural Resources Conservation Service. Conservation Practice Standard $n^{\circ}$ 600: TERRACE. National Conservation Practice Standards - NHCP. United States Department of Agriculture (USDA). 2010. Available at: <www.nrcs.usda. gov/technical/standards/nhcp .html>. Accessed: 26 Nov. 2010 .

NUNES, M.C.M. \& CASSOL, E.A. Estimativa da erodibilidade em entressulcos de Latossolos do Rio Grande do Sul. R. Bras. Ci. Solo, 32:2839-2845, 2008.

PANACHUKI, E.; ALVES SOBRINHO, T.; VITORINO, A.C.T.; CARVALHO, D.F. \& URCHEI, M.A. Avaliação da infiltração de água no solo, em sistema de integração agricultura-pecuária, com uso de infiltrômetro de aspersão portátil. Acta Sci. Agron., 28:129-137, 2006.

POSTHUMUS, H. \& DE GRAAFF, J. Cost-benefit analysis of bench terraces, a case study in Peru. Land. Degrad. Dev., 16:1-11, 2005.

PRUSKI, F.F.; FERREIRA, P.A.; RAMOS, M.M. \& CECON, P.R. A. model to design level terraces. J. Irrig. Drain. Eng., 123:8-12, 1997a.

PRUSKI, F.F.; CALIJURI, M.L.; BHERING, E.M. \& SILVA, J.M. Metodologia baseada no uso de sistemas de informações geográficas para obtenção de equações de chuvas intensas em qualquer localidade do Estado do Paraná. R. Bras. Eng. Agric., 5:254-265, 1997b.

PRUSKI, F.F. Conservação de solo e água: Práticas mecânicas para o controle da erosão hídrica. 2.ed. Viçosa, MG, Universidade Federal de Viçosa, 2009. v.1. 279p.

TEDESCHI, L.O. Assessment of the adequacy of mathematical models. Agr. Syst., 89:225-247, 2006.

ZHANG, J.H.; SU, Z.A. \& LIU, G.C. Effects of terracing and agroforestry on soil and water loss in hilly areas of the Sichuan Basin, China. J. Mt. Sci., 5:241-248, 2008. 